\title{
The Romans in Britain and the Effect of Male/Male Sexual Iconography at London's National Theatre
}

\section{Piet Defraeye}

Piet Defraeye (defraeye@ualberta.ca) is Associate Professor of Drama at the University of Alberta. In this article, he examines the phenomenology and rhetorical potential and pitfalls of male/male sexual iconography in mainstream theater. This essay is part of a book entitled Shocking the Audience, which investigates the rhetoric of stage provocation.

When reading popular as well as scholarly criticism of contemporary gay and/or lesbian theater, I am always struck by how much of this theater is still, whether we like it or not, mostly a fringe phenomenon, staged in specific theatrical venues for a specific public. The immediate concern resulting from an observation like this is how far gay/lesbian theater is culturally relevant within the larger economy of stage production, and how far and where has it claimed a position within that apparatus. There are strong indications that gay/lesbian theater has become a genre that is recognized and acquires specific signification as a result of this recognition. There are also clear indications that its rhetoric and imagery influence more mainstream poetics and cultural production. However, there are also obviously moments of clashes, in which elements are attacked as illegitimate. Ironically, as Pierre Bourdieu 
points out, these attacks can serve as "consecrating" moments through which illegitimate iconography and discourse are ultimately absorbed and assimilated, or plainly used or exploited, in the dominant cultural production that initially censored it (42).

On the topic of the structures within the field of cultural production, Bourdieu warns us that "what can be constituted as a system for the sake of analysis is not the product of a coherenceseeking intention or an objective consensus (even if it presupposes unconscious agreement on common principles) but the product and prize of permanent conflict" (34). If there is a unifying principle, it can only be the struggle itself in which the various contradictions and opposing interests claim territory and play themselves out against one another. In the theater, this is manifest mostly in the differences of programming and production policies between the big houses, or the established mainstream theater, and the more experimentally oriented and less rigidly structured small and fringe theaters.

This essay offers a critique of one of those moments of "objective collusion" when the artistic value and aptness of an artist's work is put into question (Bourdieu 80). I will do this using the tempestuous reaction to the first and only professional production so far of Howard Brenton's The Romans in Britain in 1980 at the National Theatre in London. ${ }^{1}$ In this particular case it was the sexual male/male iconography, as part of the dramatic vehicle of a mainstream dramaturgy, that was problematically received by its audience. The controversy surrounding the National Theatre's production is particularly interesting since the staged iconography was devoid of any homosocial or homosexual context while being nonetheless very explicit in its male/male polarity. While I am aware that all kinds of variables play an important role in the generation of specific audience reactions, and that these reactions can differ from one night to the other, or from one production to the next, I will

${ }^{1}$ A subsequent amateur production of the play at Swansea's Dylan Thomas Memorial Theatre (1983) was cancelled under threat of prosecution. The only amateur production, so far, that opened to the public (Cambridge's ADC Theatre, 1989) was left undisturbed despite police interviews with those responsible for its organization (Roberts 69). 


\section{2 / Defraeye}

theorize what happened at the National Theatre in order to come to a more general understanding of the position of male/male sexual iconography within the larger field of cultural production. I will start my argument by analyzing Brenton's use of violent imagery as a rhetorical strategy. Subsequently, I will problematize the literalizing effect of this strategy, which is particularly evident when it comes to the contentious male/male rape. Finally, I will show how the rape scene was divested of its figurative meaning and turned into an instance of "homosexual rape," as part of an opportunistic reaction aimed at reconfirming an established identity vis-à-vis a dissenting (and threatening) otherness.

The Romans in Britain is an epic play that deals with issues of invasion, imperialism, and colonialism, and uses the Roman and Saxon invasions of England as historical analogies of British rule Brenton would call it 'occupation' - of Northern Ireland. The play consists of two parts. Part One tells the story of the Roman invasion of Britain and the unsuccessful resistance of the Celts. Paradigmatic reflections of the main theme are contained within this general narrative of colonization. The play opens with two Irish criminals in flight. One of them is captured and ritually slaughtered as a sacrifice by a local Celtic druid named Marban, while the other one continues his flight with a Celtic slave. The news of the approaching Romans impels the matriarch of the local tribe to strike a deal with the neighboring rivals. At the center of the first part is the confrontation between the young druid Marban, his two brothers, and a trio of Roman soldiers. The two brothers are brutally murdered while the druid is violently raped by one of the soldiers. ${ }^{2}$ The first part ends with an unmatched standoff between a stone-throwing Celtic slave

2 There is a slight difference between the 1982 Methuen edition of the script (which I refer to throughout since it is the closest to the text of the 1980 National Theatre production) and the stage directions of the original publication of the play (1980). While the original reads, "The THIRD SOLDIER holds MARBAN's thighs and begins to bugger him" $(1.3,42)$, the Methuen edition says, "The THIRD SOLDIER holds MARBAN's thighs and attempts to bugger him" $(1.3,41)$. I agree with critic Meenakshi Ponnuswami (86) that the distinction makes little difference, and I will refer to "Marban's rape" and "Marban's attempted rape" interchangeably. In judicial terms, rape is rape, whether it is attempted or executed. Making a distinction between the two is critically suspect. 
and a more modern version of Roman invaders in British Army uniforms, wielding machine guns.

Part Two alternates between scenes from the Saxon invasion of England in the early sixth century and a contemporary incident set in Northern Ireland in 1980. Here, too, images of invasion and violent oppression reflect one another. The Saxon scenes follow two groups of people: a Celtic peasant named Cai, his two daughters Morgana and Corda, and a Roman matron who is dying of the plague, and is attended by her steward and two cooks. Cai, insistent in his defiance of the invading Saxons, is killed by his anguished daughter, while, similarly, the steward kills and robs his Roman mistress. The survivors of the two storylines from the time of the Saxon invasion meet and combine their energy and mythological resources to escape the tyranny of the Saxons. The contemporary story, meanwhile, interspersed with the historical narrative, tells the story of Thomas Chichester, an undercover British agent assigned to assassinate an IRA leader. Tormented with guilt, however, he reveals his true identity to the local IRA band who, unmoved by the liberal sentimentality of what they see as the oppressor, decide to shoot him. The play ends with the two Celtic cooks and the two daughters who, seated in the middle of human carnage, invent the redemptive myth of King Arthur.

It is obvious from the above that Brenton's play presents a dystopian view of history, moments of which are thematically and formally juxtaposed and parallelled on the stage. The presence of (simulated) violence on the stage is crucial in this project. If the subject of the play, in its broadest sense, is a study of history seen as a struggle for power, I would argue that Brenton decided to make the violence of this struggle appear real, individualized, and singularized on the stage in order to show the violent nature of any form of colonization or imperialism. We are witness to a number of specific interactions between individuals that are graphically laid out in front of us in a visual dramatic figure of the nature of imperialism. It is remarkable that reviewers and spectators of the 1980 production have criticized this violence, in the language as 


\section{4 / Defraeye}

well as in the action of the play, as unnecessary and ahistorical. ${ }^{3}$

The play presents history as a constant narrative of oppression. It confronts its audience with images of violent oppression, not in the poetic language or imagery of heroic historiography or monumental commemoration, but in their primary reality as bloody, cruel and deadly tyranny. In the course of the play, nine people - Daui, Brac, Viridio, Marban (suicide), Conlag, a Saxon soldier, Cai, Adona, and Chichester - and one dog are killed in full view of the audience. This amounts to ten fatal casualties not counting the few Celts killed off stage - out of a total cast of 61 . Obviously, the motif of death is central to the development of the play's argument and generates a gruesome effect, which is potentially very shocking. It is the gratuitousness and the sense of pleasure conveyed in the killing of Brac and Viridio by three Roman soldiers and the attempted rape of Marban that results in his suicide that makes this scene the single most shocking moment of the play. Three naked young men getting ready for a swim are attacked by three heavily armed soldiers. It is these three assaults that reviewers refer to in their criticism of the abundance of violence in The Romans. The Daily Express, for instance, blockbusted the play as a "Sadism Play" (qtd. in Boon, Brenton 74).

A close analysis of the reception of The Romans sheds light on the fascinating and complex effect of Brenton's dramatic choices in regard to his representation of violence and history. After the play's opening night in London at the National Theatre on October 16,1980 , the public debate about what was considered a spectacular public provocation soon hit an all-time high. London daily and evening newspapers ran bold headlines playing on the production's more sensational aspects. The Evening Standard blacklisted the

${ }^{3}$ Robert Gross, for one, isolates the rape scene as standing "apart from the rest of the play in its presentation of violence" (76). Since I am concerned with male/male iconography, I would agree to the extent that this scene stands out from the other violent interactions, but not for Gross's ill-founded reason that "All of the other violent acts in The Romans in Britain either take place offstage ... or take place quickly" (76). Gross's analysis is based on an incomplete tally of fatalities and a refusal to recognize that some of the death scenes, like the killing of Brac (1.3, 38-43) and of the Saxon soldier (2.4, 81-82) are equally gruesome and protracted in their representation on the stage. 
production as a "Nude Play Shocker," while the Daily Express cried foul with "Fury over New Sex Play" and "Police Move over Sadism Play" (qtd. in Boon, Brenton 73-74). For weeks, the controversy generated radio, television, and newspaper coverage, accompanied by an intense debate in the form of letters to the editor from readers and professional writers. The scandal also formed part of the agenda of politicians and policy makers. Sir Horace Cutler, the chairman of the then Greater London Council, walked out during one production and threatened to withdraw the Council's $£ 630,000$ grant and within a year, in March 1981, London's governing body decided not to increase its grant to the National Theatre. The controversy even reached the floor of the British House of Commons, where debates only added to the play's notoriety, thus further stimulating people's curiosity to go and see it.

The spectacle of controversy spiralled into serious complications when Mrs. Mary Whitehouse of the conservative media watchdog the National Viewers' and Listeners' Association decided to initiate a private lawsuit under the 1956 Sexual Offenses Law - which is normally only invoked for cases like indecency in public washrooms. The production's director Michael Bogdanov was charged with occasioning an act of gross indecency between two actors. ${ }^{4}$ The charges that were laid referred only and exclusively to the attempted male rape in Part One, Scene Three of the play. From this brief synopsis of the play's popular reception, one conclusion jumps out: few critics or spectators took outspoken issue with the political implications of Brenton's analysis and his ostensible simplification of the historical and political struggles that still determine the Northern Irish question. Throughout the play, the issue of Ulster Protestant claims and rights, for instance, is never adequately addressed, and it never seems to be a major source of irritation for its mostly British audience. What transpires, at least on the surface, is that the immediate and popular reaction to the play has less to do with matters of historical interpretation and much more to do with male nudity and aspects of male-male sexual iconography. 
Most of the reviewers of The Romans criticize the production's abundance of violence, but in the same breath they critique the representation of this violence as not being explicit or accurate enough. In other words, they want more or, at least, want better violence, that is, more real, less structured and more turbulent violence. One critic, for instance, James Fenton of The Sunday Times attacks the play as lacking in realism, not only in its use of language - "a ludicrous pseudo-poetic yob-talk," he calls it - but also in its representation of violence. He writes about the sacrificial cutting of a Celt's throat in the second scene of Part One, which for his taste did not draw enough blood: "in real life, the supply would be less manageable and more plenteous." He continues in the same fashion on the enactment of the rape of Marban by the Roman soldier: "I have not seen that much anal rape in real life, but I imagine it to be rather more messy than what we are shown"; and the review goes on with similar objections. Fenton's remarks are particularly revealing because he uses only the actors' real-life names, without any reference to their function as characters in the play: "the blood must gush from James Carter's throat ... while Peter Sproule must appear to get it up Greg Hicks, in full view of the audience and with the pair of them bollock-naked." Fenton's report delivers a testimony of the kind of action for which the police are to be called in to lay charges. Something rather extraordinary has happened in the critic's mind in this instance - something like a poetic eclipse in which the representation is reduced to a presentation.

A closer look at Brenton's use of violence, however, reveals a strategy with a certain purpose within the dramatic reality of the play, in contrast to what many reviewers of the production seem to suggest (Chaillet; Fenton; Murray; Nightingale; Oakes; Shulman; Young). Most of the violent scenes are logical or even necessary outcomes of the dramatic conflict. Three of the ten onstage killings are done out of a sense of protection and in a sacrificial way. The Irish drifter Daui, the Saxon soldier, and the English agent Chichester are perceived as trespassers in a closed community and they are sacrificially slaughtered by community members who believe they will obtain protection against the dangers of oppression and invasion that each of the trespassers represents. Cai and Adona are perceived as tyrants and are executed out of a desire for freedom. 
Corda, Cai's murderer, and Adona's steward find themselves in a state of slavery and hope to terminate their serfdom by exterminating their master. And Marban's suicide is obviously a regressive resolve to his being raped and captured by the Romans.

There is, in other words, at least some sense of system and purpose to the aggression in the play: Brenton's use of violent rhetoric and imagery in the play is an essential part of his dramatic strategy. In The Romans, he wants to convey his conviction that the British presence in Northern Ireland is yet another manifestation of British colonial aggression. The fact that he chose a scene of male/male interaction as the very core of his deconstruction of historiography is no coincidence. Whereas colonization is more familiarly rendered as representations of male conquest of the female body, eroticized or not, I would argue that colonization is a narrative fundamentally characterized by male/male power struggles. With The Romans, Brenton opted for a short-circuiting of these more conventional representations and, instead, chose an iconography that exhibited the sexual conquest of one male over another, thus exemplifying the homosocial dynamics of the conflict.

The fact that the violence is compelling and confrontational reflects Brenton's aim and strategy. But the potential effect of this equation on a largely British audience may lie somewhere between alienation and rejection, on the one hand, or recognition and guilt, on the other hand. In the play, both are shown to be mere denials of or inadequate responses to this legacy of aggression. One of Chichester's final comments, seconds before he is shot, reveals his discomfort with his imperial heritage:

I keep on seeing the dead. A field in Ireland, a field in England. And faces like wood. Charred wood, set in the ground. Staring at me. The faces of our forefathers.

Their eyes are sockets of rain-water, flickering with gnats. They stare at me in terror.

Because in my hand there's a Roman spear. A Saxon axe. A British Army machine-gun.

The weapons of Rome, invaders, Empire. $(2.7,97)$

But this recognition cannot rescue him from his imminent execution. What happens on the stage seems to be a reflection of what is meant to happen in the auditorium: Brenton is not looking for relief in the 


\section{8 / Defraeye}

play's outcome nor is he offering any alleviation in the (British) audience's reaction to a representation of their own past. His mistrust of language in general and historiography and so-called historical consciousness in particular is reflected in his eagerness to show the violence and aggression that have been objectified and made palatable by history itself.

In his critical reflection on violent theatricality, David Graver asks to what extent the stage can "embody aggression and pain without becoming something else or without the aggression and pain becoming (uneasily) their own simulacra" (43). In the spectator's eye, the performative character of the rape scene is undercut and divested of its theatrical phenomenology. In its place, another level of reality is divulged and the focus is now on the action itself as it is literally done and not performed-the action is no longer done by characters, performed by players, but by actors engaging in a deed. Consequently, as in the case of Fenton, the focus of perception is to be located in the how? of the action rather than the why?: "The only interest [of the spectator] ... is technical" (Fenton). The engulfing effect of what is shown leads to a certain degree of spectacularization of the representation in the process of which fragments can easily be isolated and assessed on technical or practical - as opposed to hermeneutic - grounds.

Spectacular elements characterize the play and its production in a fundamental way. The story itself, in its conflation of history, is of an epic nature which is most readily representable in a spectacular fashion. It is also significant that at the most intense moments in the play, this spectacular disposition is written into the script, almost as a means to deflate and counteract the tension. The emergence of the Roman army in modern British uniforms and with army equipment is a spectacular coup de théatre; the search of the British soldiers in a cornfield occupying the entire stage, the spectacular merging of two temporal frameworks on the one stage and the abundance of visible violence work in similar ways, especially as they were enhanced by Michael Bogdanov's direction and Martin John's expressionistic production design (Boon, Brenton 
184-85). ${ }^{5}$ This tendency toward spectacle is clearest in the most controversial scene; there are some remarkable stage directions, which can help us in reconstructing the event. While the third soldier is preparing the attempted rape, the first soldier starts cartwheeling over the stage until he "cartwheels off, into the river, out of sight" $(1.3,41)$. After he disgruntledly aborts his rape of Brac, the third soldier "runs into a handstand. He jack-knifes out of it" and dives out of sight into the river $(1.3,42)$. The effect of these gambols on the perception of the action must necessarily be very complex. While the attempted rape, in all its crude literalness, clearly has a figurative or metonymic function, this function is immediately neutralized by the frolicking and frivolity of the three soldiers in a gambol routine which belongs more in the spectacle of the circus than in the representation of conquest. The effect of this digression is, of course, that the hideous cruelty of the invaders is reinforced by placing it in a frivolous context. This is to say that the focus is the immediacy of the violation, which is truly perceived as a violent transgression or penetration in more than one sense of the word. However, in this focus on the immediacy of the scene, and because of its spectacular placement, the meaning of rape and penetration is narrowed down to what is actually being done on the stage; it is, in other words, literalized in line with the literal gambols of the assailants. This is, of course, the intended effect: the violence is shown as a real violation and not just an image. However, this literalization also sets another effect in motion which may not have been so intended: what is shown is ultimately dehistoricized and depoliticized in the shocked gaze of the spectator. In this way, and largely because of the blending of a spectacular and a theatrical mode, the provocation is intensified but, eventually, stands in its own way and eclipses its own meaning.

The debate in the courtroom on The Romans was, in a way, characteristic of this literalizing reception by the press and its audience in general. A major concern for the lawyers during the

${ }^{5}$ This fusion of historical references and dramatic exploitation of violent scenes on the stage has since become a trademark of director Michael Bogdanov's dramaturgy and was particularly noticeable in his production of The Henrys (1987), based on Shakespeare's Henriad (see Rissik). 
committal proceedings, as well as during the trial itself was whether or not the tumescent body part that was seen protruding from the actor's body was his penis or his thumb. ${ }^{6}$ The reduction then, within the judicial argument, of the play's contextual landscape and of its dramatic reality to the one scene of male/male rape is, in fact, characteristic of what happened to its reception by the press. This process of reduction to the practicalities of representing anal sex reaches beyond its obvious strategic use for the lawyers in the court case. It is a typical condition of and reaction to provocative theater, where the reduction goes hand in hand with a process of amplification. That which is perceived to provoke is taken out of its dramatic context. The context is thus reduced to the provocative element itself which now gets all the attention and, consequently, acquires a more important function within the play. This phenomenon allows for an even greater spiralling effect of shock which is fed upon by this reductionist reception. Isolated from its dramatic context, the provocative scene loses its potential for figurative signification and is subsequently recontextualized by the spectator in another reference system. In this case, the original dramatic context of imperialism and military, ethnic and or cultural aggression is lost to a curious and perhaps perverse concern with the action itself. Brenton's deliberate choice of violent, sexual, and transgressive imagery is thus appropriated by a new, more literal context in the service of predominant moral codes and social norms. A significant section of the fairly middle-class patrons of the National Theatre ${ }^{7}$ categorized the language or actions in question as

${ }^{6}$ Peter Sproule, who played the Third Soldier, took the prosecution witness's testimony that what he had seen was a man's penis entering another man's anus as a great tribute. Not only did he thus compliment the actor's virile image, seeing him capable of ordering his erections at will, even in front of an audience, but he also commended his convincing and apparently verisimilar acting talent. Still, in the courtroom, the irony was missed; in the lawyer's mind this was beside the point. As John Sutherland puts it: "For the law, it was either a penis ... or a thumb" (190).

${ }^{7}$ One must not forget that 1980 was the nexus of Thatcherite conservatism in England. To my knowledge, there are no sociological studies available linking theater audiences of the National - or any other theater - to contemporary sociopolitical stratifications. The fact that the Thatcher government, in the person of its Minister for the Arts Norman St. John-Stevas, pursued the matter in Parliament indicates its ambition for 
not only real, but also inappropriate and unacceptable, thus preventing the possibility of metaphorical or metonymic meaning. Subsequently, The Romans in Britain became a story of buggery in the public's perception. David Graver's postulation that "violence generally destroys theatricality"(46) seems particularly valid when violence is a product of and/or results in male/male buggery.

Defining the rape as "homosexual," as so many critics do, ${ }^{8}$ is problematic for various reasons. The use of the term "homosexual" in the critical discourse on the play clouds the issue of the scene's figurative meaning. A considerable segment of those who took issue with the play in general or with the rape scene in particular undoubtedly consider homosexuality itself as a transgression or an abomination, which suggests the ease with which "homosexual" as a descriptive term can consolidate homophobia." Even apart from these homophobic reactions, the epithet "homosexual" puts the focus on the sexual dynamics between the two persons involved and draws attention away from the aggression and transgression involved in rape. Nowadays, it is generally accepted that rape has little to do with sexual gratification and must primarily be understood as a violent assault; hence it would be problematic to use the term "heterosexual rape" to denote the more familiar occurrence of rape. Richie J. McMullen, in his groundbreaking study on what he calls "male rape," goes even further and calls "homosexual rape" a "misleading" term when it "is used to mean male rape." For him, homosexual rape is an activity that "involves one or more homosexuals raping another homosexual" (52). Clearly this is not the kind of scene Brenton envisions in The Romans. In the dramatic reality of the scene in

political gain from the scandal.

${ }^{8}$ See Beacham (36); Boon, Brenton (173); Chaillet; Gross (76); Hobson (29); Itzin, "Sex" (11); Judd; Lahr (173); Ponnuswami (69); Roberts (59); Weiner (58).

${ }^{9}$ A particularly useful example of this attitude, in the context of the reception of The Romans, is an unrelated, but contemporaneous remark by Lord Chief Justice Lane who criticized the fact that society "deliberately blurs these boundaries which ought above all to be clearly defined ... The men who, by today's jargon are described as gay, are not gay, they are homosexual and/or buggers and it is a pity that they are not called that" (qtd. in Rayside 138). 
question or of the play in general, there is no referential framework present that even remotely refers to homosexuality. And yet, as the above examples show, the outrage that was generated by this scene was very much of a homophobic nature. ${ }^{10}$

Some critics take this homosexualizing reading of the play even further. Toward the end of the rape scene, the second Roman soldier, in an emollient gesture, kisses the stricken Marban. The priest/rape victim reacts indignantly with a passionate denunciation of the Romans in Latin, the aggressors' own language. Robert Gross sees an act of "homoerotic tenderness" (78) in this scene, which contrasts with the violent nature of the rest of the play. This contrast, Gross goes on, is so abrupt and "weakly motivated that it strains the sense of psychological verisimilitude otherwise adhered to in the play" (78). Gross relates this ambivalence to "Brenton's uneasiness about the loss of phallic power" and the subsequent "loss of traditional male identity" (79). The problem with Gross's view is that he explicitly sees the rape as "Homosexual violence," which then becomes "the act of male dominance par excellence, because it is an act of conquest and domination" (77). Apart from a few minor inaccuracies in his argument, Gross fails to incorporate the problem of language in his reasoning - Latin, Celtic and English are each used as part of a particular rhetorical strategy, as I will show - and he overlooks the fact that women in the play - the Celtic Matriarch and the Roman matron Adona, to name only two - are also portrayed in positions of power, albeit in a threatened state. I concur with Ponnuswami that the Celtic and Irish resistance in The Romans is characterized by a degree of "feminization" (87), though I question the critical usage of the term in this context as it camouflages its own bias and point of view. Brenton's apparent reversal of gender and sexual roles may not be the result of a problem in the author's personal sexual politics, as Gross suggests,

${ }^{10}$ Ironically, the homophobic nature of the court case itself is mostly evident in the mere fact that there probably would have been no legislation to fall on, if the rape scene had been staged between two characters of the opposite sex. The relevant passages of the 1956 Sexual Offences Act apply exclusively and explicitly to homosexual sexual activity. I am not aware of contemporary legal challenges in the U.K. concerning stage representations of male/female sexual iconography. 
but part of a strategy to problematize his own narration of colonization in which typically the topography is male-centered.

The controversial rape scene, as part of a historical chronicle, seems to fit in the contemporary historical background of sex, sexuality, and the sexual mores of the early Roman period. In ancient Greece and Rome, sex was not divided along exclusive gender lines, as in hetero- and homosexuality, but along an active/passive axis. Sex, in other words, was not a declaration of sexual identity but rather of sociopolitical identity. Referring to Athens and Rome, David Halperin remarks, "The relation between the 'active' and the 'passive' sexual partner is thought of as the same kind of relation as that obtaining between social superior and social inferior, between master and servant. 'Active' and 'passive' sexual roles are therefore necessarily isomorphic with superordinate and subordinate social status" (49). Paul Veyne concurs with this opinion by concluding that the decisive factor in sexual activity was the question of whether one was active or passive: "To take one's pleasure was virile, to accept it servile" (30).

It is obvious that the phallus, not only as a specific item of male anatomy but also as a symbolic vehicle of sociocultural signification, plays a crucial role in the construction of this identity. In this respect, it can be argued that it makes sense to refer to ancient Greek and Roman sexual experience as, in Halperin's words, "a single, undifferentiated phallic 'sexuality' of penetration and domination, a sociosexual discourse whose terms are phallus and non-phallus" (51). During war campaigns, it was far from uncommon for Roman soldiers to molest their prisoners and use them as sexual outlets or sexual impudicus. ${ }^{11}$

The rape scene must be situated within this historical context of phallus versus nonphallus. At no point in the

${ }^{11}$ In The Romans there is one apparent exception to this categorization of phallus versus nonphallus within the group of colonizers in the person of the Roman matron Adona. However, it is significant that Brenton chooses a woman as a representative of disintegrating Roman political power, since women in Rome were without real power in the first place. Adona's repeated orders to whip the two insolent cooks during Scene Seven of Part Two, are consistently left unanswered by her steward/paramour. He is the one who exercises the real power, and ultimately decides to kill her. 


\section{4 / Defraeye}

confrontation between Marban and the third soldier is there any reference to or interest in the genitalia of Marban; Marban is effectively desexed by his assailant. The only thing that counts here is the receptive position and potential of Marban, regardless of his gender, a reduction which is made abundantly clear in the third soldier's comment on the state of Marban's "arse" and the aggressor's apparent shame in his unsuccessful attempt at penetration. His concern is that nobody back home learns of his "not getting it up a British arseful of piles," whatever gender it belongs to $(1.3,42)$. The emphasis on phallic penetration in sexual release is also reflected in Caesar's comment on the Legate's sister. As a final humiliation of his commander, now fallen into disfavor, Caesar offers a knife as a gift to his sister: "Look, send this knife to your sister, as a present from me. Tell her-(He toys with the knife.) to guard with this knife, what I would enter as a knife" (54). Again, the genitalia of the recipient play no role; what is important is the presence of a passive, receptive vessel for the phallus. Its semantic significance of transgression lies not only in the literal penetration of the other without any sense of consensuality, but also in the ensuing metonymic figure of domination and appropriation. Hence, the rape scene appears to make perfect sense within the political project of The Romans.

The fact that Brenton chose a druid or priest as the victim of his rape scene makes the transgressive act all the more violent. It also allows the author to establish a subtle irony in his use of language. While Ponnuswami critiques the authenticity of the voice of Brenton's Celtic characters and questions his linguistic representation of Celtic identity which she suggests is "little more than versions of an imperial fantasy" (73), in the rape scene, his use of language is meticulously strategized for a particular rhetorical effect. This effect is the result of Brenton's use of a dramatic convention, in which characters who belong to different linguistic groups can be understood by one and the same audience. In The Romans, this effect proves particularly manipulative and brings about a situation where the audience is complicit in an aggressive act and is, thus, found to be in a belligerent or colonizing position. It is important not to forget that the two opposing parties in this scene do not understand each other, which means that the Romans' verbal 
abuse is not received as such by the three Celtic brothers. Indeed, it is exactly the fact that the Celts speak another language, categorized as primitive by the conquering Romans, that gives the latter licence to conquer, empower, and kill. It is their language, perceived as animalistic gibberish, which forms the basis for them to be othered by the conquering Romans. It is this sort of rationalization that has acted historically as a justification for imperialistic conduct based on a sense of superiority. The fallacious and arbitrary character of this rationale is suggested dramatically by the fact that both parties $d o$ speak the same language - which is English - not for each other, but for the audience, as part of a theatrical convention (Itzin, "Sex" 5). For the spectators, the two opposing parties are linguistically on equal footing. However, the realization that the verbal abuse of one party directed at the other registers as such only for a third party, the audience, makes the latter linguistically complicit in the act of violence.

This effect of complicity is intensified by the fact that the Celts remain silent throughout most of the rape scene. True, verbal opposition would be of little avail since their opponents, who are trained and armed soldiers, can easily ignore sounds which do not make sense to them. Yet, at the end of the scene, it becomes clear that Marban, with his training as a druid, can speak some basic Latin, the Lingua Franca at the time - something which he has kept to himself even while he was being sexually assaulted. In view of the agonizing circumstances, this suggests a curious sort of self-control which intensifies the shocking quality of the scene. ${ }^{12}$ The momentary absence of any communication between the Roman

12 Gross compares Marban's ability to speak Latin with a miracle which "snaps" the verisimilitude of the play (78). Marban's knowledge of at least some Latin, however, is referred to in the beginning of the rape scene when Marban translates for his two brothers the Romans' murderous intentions: "BRAC. Jabber jabber./ MARBAN. They're talking about how to kill us" (The Romans 1.3, 37). Marban's knowledge of Latin is supported by historical research on the Celtic druids. There was extensive contact between Britain and the continent, even before the first Roman invasion of Britain in 54 $\mathrm{BC}$; especially the Druids on either side of the Channel had established extensive rapports (Chadwick 41). There is evidence that the Druids used the Greek alphabet and also knew the language (Chadwick 102). Nora Chadwick, one of the most authoritative scholars of druidism, concludes that they also knew Latin, or at least the basics of it ( 9 and 106). 
soldiers and their victims allows the first to objectify the latter even more. In fact, the only effort to communicate their fear and anger or humanness - on the part of the Celts, comes from Viridio, just before he is about to be killed. In a long-winded but poetic speech, full of bloody and violent imagery, Viridio forewarns of a violent revenge on his assailants: "Foreigners, I will hold your heads in my hands. With my fingers in the sockets of your eyes, I will hold up your skulls, wet with the flesh of your eyes and your blood! I will know you as a killer!" $(1.3,38)$. It is hard to resist the impression that the "foreigners" Viridio is addressing, by implication, include the present audience. This becomes quite evident toward the end of Part One, when, in a spectacular coup de théâtre, Julius Caesar and his army appear "in British army uniforms and with the equipment of the late 1970s" $(1.7,62)$. At this stage, the analogy has lost its subtlety and the point that the British themselves are, in fact, the foreign invaders of the play's title is driven home forcefully. The most likely reaction of a British audience would be an immediate self-distancing from what is perceived as an accusation.

During the rape scene, however, the dramatic signals that are used in the analogy, with the notable exception of the moment of rape itself, are more discreet and thus, perhaps, more manipulative. Situated in the middle of a rather realistic and rapidly evolving dialogue, Viridio's sudden interruption of the verbal pace and of the action functions as a soliloquy directly aimed at the audience. Moreover, as already indicated, the whole passage is not supposed to be understood by the assailants, and the first soldier's echo of Brac's initial reaction to the Romans' language, "Jabber jabber" $(1.3,39)$, reminds the audience of the Romans' insusceptibility to the suffering and foreboding of the Celts, while the spectators are pushed into a position of complicity. This complexity is intensified by means of a long silence on the part of the Celts throughout most of the rest of the violent rape. Viridio's soliloquy is thus a last effort to retain their pride and integrity at the hands and mercy of the Roman invaders. The effect renders a bleak contrast between two different kind of rhetoric, or two different uses of what for the audience is one and the same language. The casual, short-sentenced, ungrammatical, and nonsensual speech of the soldiers contrasts with Viridio's ritualistic, elaborate, and expressive malediction. What 
follows is silence on the part of the Celts, a universal language, which needs no translation for either the Romans or the audience; its effect is reinforced by the the screaming and moaning of Brac, the first slain Celt, through most of the scene, as the stage directions indicate $(1.3,38 ; 39 ; 43)$ and the occasional moan by Marban while he is being worked on by his molesters. When Marban breaks the silence at the end of the scene, and denounces his assailants in their own language, their reaction is one of confusion and shock: "A nig nog? Talking Latin? ... This nig nog talks Latin!” $(1.3,43-44)$.

The effect of Marban's Latin denunciation is unsettling for the Romans because it humanizes their victims and creates a disturbing dichotomy between the brutal actions and the unexpected rapport that is established. It is ironical that this humanizing effect vis-à-vis their assailants happens in a language which now is not normally understood by the audience; consequently, the spectators are in a no-win situation. They are aligned once more with the invading foreigners that feature in the play. It becomes clear that the audience's reaction of shock to what amounted to be a provocation was exacerbated by Brenton's rhetorical strategies, which reflect the violent imagery of transgression.

The focus of much of the audience, however, was not so much on the violent appropriation that is implied in the scene, but rather on the so-called homosexuality of the rape of one male by another. Apart from the epithet "homosexual," other terms that were often used in reviews and letters to newspapers in reference to the rape scene were "buggery" and "sodomy" (Cutler; Grecco; Milligan; Osborne; Ottoway; Young). ${ }^{13}$ The usage of these terms, rather than the more neutral "rape" or more clinical "anal rape" (Edgar; Fenton; Levin), is a further indication of the disparaging response of some of these spectators. It is, of course, difficult to determine whether their usage in this context is simply a consequence of the more

${ }^{13}$ For a list of reviewers who call the rape "homosexual," see footnote 6 . It is interesting to know that for English law, anal rape, whether the victim is male or female, does not have the same gravity as (female) vaginal rape (McMullen 21). There is, consequently, a remarkable legal discrepancy between male rape and female rape. While the maximum sentence for female rape is life imprisonment, for "indecent assault on a male" it is ten years imprisonment (McMullen 15). 


\section{8 / Defraeye}

homely and colloquial nature of these terms - as in "what a silly bugger" - or whether it is a deliberate choice in function of the persistent pejorative connotations that are connected with them.

In Brenton's economy of theatrical images, the rape scene is not only crucial in conveying his convictions of imperialism and colonialism, it also serves as a provocation to his audience's economy of imagery. By opting for a male/male rape rather than a male/female rape Brenton avoided the kind of scenario that is dreaded by feminist criticism which points out that, often, representations of rape will be received in a convoluted critical language because of our difficulty "to establish difference through the opposition of rape to seduction" (Rooney 1271). Reading sexual violence is a hazardous occupation because of the persistence of "the very patriarchal dichotomies we seek to disentangle ourselves from" (Rooney 1271). This is particularly so in the case of conflicts that are specifically set in a male/female context. ${ }^{14}$ Ironically, The Romans' reception is an example of this acquiescent attitude towards the motif of male/female rape, which is present in the play, but was completely disregarded not only by the protesting audience, but also by the critical apparatus that developed around the controversial play.

When, at the end of Part one, the runaway Irish criminal, Conlag, reemerges with his captive Celtic slave, she laments, as in a stupor: "He did rape me in the forest" (1.6-61). Subsequently, she picks up a stone and dispassionately kills her delirious companion and assailant. Evidently, this rape did not take place on the stage, and, therefore, cannot be compared with the rape in scene three. Its absence from the stage may well be an intentional choice so as to avoid imagery that, because of its consuetudinary character, would cause a reaction of complacency in the audience, especially in

${ }^{14}$ It is tempting to compare the reception of The Romans with that $\mathrm{cf}$ contemporary plays or productions in which a female character is raped by a male. Such comparisons are questionable due to the different circumstances and different semantic contexts of the rape scenes. One such example is Marisha Chamberlain's Scheherazade (1984). Its numerous productions across North America occurred without much protest against the graphic representation of the multiple rape in the play, although critics were quasi-unanimous in calling the play "harrowing in the extreme, almost unbearable to watch at times" (Chapman). The play's subject is sexual assault of females by males. In Chamberlain's play, the rape refers quite literally to sexual aggression itself. 
combination with the effect of intimacy and epic remoteness on the Olivier stage. ${ }^{15}$ In spite of its potentially shocking quality, an image of a female raped by a male, at some level, fits into a structure of expectations, which is a result of what has been called our "rape culture" (Buchwald). The occurrence of a male/female rape in the play was never brought up throughout the public debate, and virtually no critic mentions it in any critical appraisal of The Romans. This blatant absence is perhaps one of the single most outstanding aspects in the reception history of the play. While Brenton's play, in its gender-reversals of power and in the rape scene, problematizes a phallocentric narration of colonization, the public outcry over The Romans and the resulting homosexualization of the play fits quite comfortably into a male-centered discourse.

Brenton's rape scene obviously provides an occasion in which a more conservative audience is confronted with a fragmentation of their rigidly structured desires. ${ }^{16}$ The mechanisms of this projected perception are undoubtedly of a complex nature. The principal causes lie, most likely, in a tradition of both psychological and sociopolitical forms of homophobia and -. connected with or because of this tradition - in negative attitudes to

${ }^{15}$ The Olivier is the main stage of the National Theatre, a combination of proscenium and thrust stage, with the sharply tiered seating area snugged around it. Numerous theater artists, like Michael Gambon and Peter Wood to name but two (Lewis 123-24), have referred to the sense of intimacy that can be created on this open stage, in spite of its size. It may well be argued that the provocative dramatics embedded in the production of The Romans were encouraged by a combination of this effect of intimacy and the epic dimensions both of the stage and of the play itself.

${ }^{16}$ A similar, though by far less intense uproar was caused by Joe Orton's What the Butler Saw eleven years earlier, when audience members barracked the opening night at London's Queen's Theatre. In this play too, the penis plays a crucial role, be it more as a farcical prop. A penis from Winston Churchill's statue gets accidentally embedded in one of the female characters, causing her death. Towards the end of the play, Sir Winston is reunited with his penis, to the audience's great delight and/or relief. Martin Esslin's critical response to the scene is memorable. In his words, it brings about the "Restoration of the nation's fertility symbol to its rightful place" (106). The Romans, unlike Orton's play, does not offer any comie freedom or release, and when that rightful place for the nation's symbol must be looked for between the buttocks of a naked male priest, obviously no restoration of any kind comes forth. 
anal intercourse, especially in a male/male context. ${ }^{17}$ More than anything else, however, this perception of perversion was the result of the generally conservative climate of the sexual sociopolitical debate that was going on in England at the time of the production. Dollimore's observation on cathexis seems quite applicable to what happened during The Romans controversy:

The culturally negated other becomes the focus of the very desire which is being policed within the dominant culture: the other, in the very process of being identified, displaced and negated, becomes the object of - indeed may actually incite - desire. Such desire for the other may be less the result of a desublimation of repressed desire than a consequence of desire itself being structured by social repression generally: thus the other may be cathected as (an)other beyond repression. (244)

The rape on the stage is thus cathected into an altogether different thing, away from its metonymic image of oppression, and provides an occasion to demand the restoration of familiar and unyielding structures, including those, ironically, of colonization. ${ }^{18}$

There is a strong sense that Brenton expected or even hoped for what was inevitably coming. Howard Brenton was not an unknown to the National's audience. Two months before the premiere of The Romans, his translation of Brecht's The Life of Galileo opened for a successful run at the Olivier, and in 1976 Weapons of Happiness was performed on the Lyttleton Stage as the first of what was called "the new generation" of plays. Although Brenton had clearly gained legitimacy as a playwright, he believed that "the theatre belongs to the centre of public life - and should be as loud as parliament. That is what a big theatre should be ... big in order for large numbers of people to see it and for it to begin to reverberate, for it to be discussed, for it to be a national event, for it

(121-49).

17 See Dollimore (233-34). On homophobia in England, see Rayside

18 Mary Whitehouse's loud concern to protect men and "young boys" is a clear example of this perverse colonization: "One is concerned about protecting the citizens, and in particular young people. I'm talking about men being so stimulated by the play that they will commit attacks on young boys" (qtd. in Weiner 59). 
to be news" (qtd. in Itzin, Stages 192). The aspiration to see theater spilling into the streets was, of course, not new: many playwrights sought inspiration in Guy Debord's Situationism and reintegrated onto the stage his concept of life as a public and orchestrated spectacle. ${ }^{19}$ Brenton had a similar project in mind when embarking on The Romans.

When he was offered a chance to write a play for the main stage of the National Theatre, the provocative quality of Brenton's project was, in a certain sense, to dissociate himself from the establishment for which he was writing while reaching an audience that went beyond what he was used to in the fringe theater circuits. ${ }^{20}$ Once Peter Hall had commissioned him to write The Romans, Brenton was careful not to allow earlier infringements on his creativity to be repeated. On the contrary, he exploited the licence given to him by Hall and his director Bogdanov and exploited the aura of respectability and authority by the mere fact of staging a play on the Olivier stage. Had the play been performed at, say, the small experimentally oriented Cottesloe stage, the outrage among the public might have been totally absent or, at the very least, much more subdued (Weiner 67). Instead Brenton, with the legitimacy he had gained in the years before, brought his theatrical bomb on sacred ground, to a stage which functions as the high altar of British theater and culture. In this context, it is important to note the curious dialectic dynamics of establishment rejection and support. The

${ }^{19}$ See Guy Debord. For a more extensive analysis of the connections between Situationism and Brenton's theater, see Boon, Brenton (54-56); Boon, "Politics;" and especially O'Connor.

${ }^{20}$ It was also a way of getting back at British institutionalized theater for the inhibiting effects it may have on the writing of plays. One particularly sour experience for Brenton was his 1972 adaptation of Measure for Measure for the Exeter Northcott Theatre. In the play, Angelo is modeled on the right-wing extremist Enoch Powell and the Duke on the more moderate Tory Harold Macmillan. Under the threat of a lawsuit from Powell, the Board of the Northcott Theatre ordered Brenton to alter his playscript. Not having gained an established reputation, the playwright had to yield under pressure. $\mathrm{He}$ later commented: "It was the first time I had ever worked inside a big theatre in England. I got an inch inside the door and they had me by the balls" ("Disrupting" 23). That establishment got back with a vengeance, not so much at Howard Brenton but at the National Theatre. Within a year, the Greater London Council decided not to increase its grant to the National, which effectively meant a $15 \%$ cut in subsidy (Itzin, "Sex" 6). 


\section{2 / Defraeye}

establishment rejection came by way of legal interventions, censorship threats, financial pressures, political and journalistic questioning and rejection by such celebrities as Pinter and Osborne. ${ }^{21}$ On the other hand, establishment support came in the form of the public forum and respectability, provided by the Olivier stage, the National Theatre's endorsement, and the defence of various established writers and actors like Edward Bond and Laurence Olivier (Bond, Edgar, Hampton and Olivier).

Looking back on the controversy, Bernard Weiner sums up the impact of the play's venue accurately by noting that "Bluenoses rarely make their objections public unless the art in question invades their turf. As long as it remains in some out-of-the-way fringe theatre or gallery, nothing much is said; if and when that art enters the bourgeois mainstream, implying the imprimatur of middle-class acceptance, then the merde begins its inexorable movement toward the fan"(67). Brenton's play became an active artistic presence within a cultural field, and the field in which he chose to operate was part of a mainstream and established system of cultural production. His strategy proved successful for the box office. The Romans drew large numbers of people to the twenty-four scheduled performances at the National, with an average occupancy of $75 \%$, which was $15 \%$ higher than anticipated (Lewis 146). As Pierre Bourdieu points out, the "production of discourse (critical, historical, etc.) about the work of art is one of the conditions of production of the work" (35).

In other words, the controversy became part and parcel of the play's production and, in a ironic way, paralleled the motifs of power and colonization that were at the center of the play's theme. Brenton's economy of imagery was clearly not valorized as a very legitimate cultural exchange by a significant and controlling section of the apparatus of cultural production. What happened to The Romans is a classic example of Bourdieu's theory of cultural dominance within a field of cultural production, which he describes as "the site of struggles in which what is at stake is the power to

21 See their respective letters to the Guardian. Osborne's letter was characteristically short and sharp: "Sir, I don't go to the theatre to see a lot of buggery. We get quite enough of that at home. Yours faithfully ..." 
impose the dominant definition of the writer and therefore to delimit the population of those entitled to take part in the struggle to define the writer" (42). The fact that the National Theatre's staging of The Romans remains the only professional production of the playscript so far is at least one indication of who was or is doing the defining and on what basis it is done. The ongoing debate whether the controversy surrounding The Romans was inspired mostly by the implied politics of Brenton's play or the perceived homosexuality may not be all that relevant in the understanding of the playscript. What is clear, however, is that the conservative establishment in Britain at the time saw homosexuality where it was not to be found in order to maintain its grip on the economy of cultural production.

Thanks to Lisa Darrach, John L. Plews and Heather Zwicker for their expert editing of this article.

\section{Works Cited}

Bamigboye, Baz and Michael Owen, "Fury over Nude Play Shocker." Evening Standard [London] 17 Oct. 1980: 1, 2. Boon, Richard. Brenton: The Playwright. London: Methuen, 1991. - "Politics and Terror in the Plays of Howard Brenton." Terrorism and Modern Drama. Ed. John Orr and Dragan Klaić. Edinburgh: Edinburgh University Press, 1990. 13850.

Bond, Edward. "The Romans and the Establishment's Fig Leaf." The Guardian 3 Nov. 1980. (Rpt. in Theater [Yale] 12.2 (1981): 39-42.)

Bourdieu, Pierre. The Field of Cultural Production. New York: Columbia University Press, 1993.

Brenton, Howard. "Disrupting the Spectacle." Interview with Peter Ansorge. Plays and Players July 1973: 22-23.

Measure for Measure. Three Plays. Ed. John Bull. Sheffield: Sheffield Academic, 1989. 89-164.

"Petrol Bombs Through the Proscenium Arch." Interview with Catherine Itzin and Simon Trussler. Theatre Quarterly 5.17 (1975): 4-20. (Rpt. in New Theatre Voices 
of the Seventies: Sixteen Interviews from Theatre Quarterly 1970-1980. Ed. Simon Trussler. London: Methuen, 1981. 85-97.)

The Romans in Britain. Rev. ed. London: Methuen, 1982.

Buchwald, Emilie, Pamela R. Fletcher and Martha Roth, eds.

Transforming a Rape Culture. Minneapolis: Milkweed Editions, 1993.

Chaillet, Ned. "The Romans in Britain: Olivier." Rev. Times 17 Oct. 1980: 11.

Chadwick, Nora K. The Druids. Cardiff: University of Wales Press, 1966.

Chamberlain, Marisha. Scheherazade. New York: Dramatists Play, 1990.

Chapman, Geoff. "Raw and Powerful Stuff: Scheherazade's a Shocker." Rev. of Scheherazade by Marisha Chamberlain.

Toronto Star 25 Apr. 1993: C2.

Cutler, Horace. Letter. Guardian 8 Nov. 1980.

Debord, Guy. La Société du spectacle. Paris: Buchet, 1967.

Dollimore, Jonathan. Sexual Dissidence: Augustine to Wilde, Freud to Foucault. Oxford: Clarendon, 1991.

Edgar, David. "The Lurking Threat to Radical Theatre." Guardian 20 Mar. 1982: 10.

Esslin, Martin. "Joe Orton: The Comedy of (Ill) Manners." Contemporary English Drama. Ed. C.W.E. Bigsby. London: Edward Arnold, 1984. 95-107.

Fenton, James. Rev. of The Romans. Sunday Times 19 Oct. 1980: 16. (Rpt. in You Were Marvellous: Theatre Reviews from the Sunday Times. London: Cape, 1983: 134-36.)

Graver, David. "Violent Theatricality: Displayed enactments of Aggression and Pain." Theatre Journal 47.1 (1995): 43-64.

Grecco, Stephen. Rev. of The Romans and Plays for the Poor Theatre. World Literature Today 55.4 (1981): 673.

Gross, Robert F. "The Romans in Britain: Aspirations and Anxieties of a Radical Playwright." Wilson 71-84.

Halperin, David. "Sex Before Sexuality: Pederasty, Politics, and Power in Classical Athens." Hidden from History: Reclaiming the Gay and Lesbian Past. Ed. Martin Duberman et al. New York: Nal Books, 1989. 37-53. 
Hampton, Christopher. Letter. Guardian 8 Nov. 1980.

Hobson, Harold. "Hobson's Choice." Drama 139 (1981): 27-30.

Itzin, Catherine. "Sex and Censorship: the Political Implications." Red Letters 13 (1982): 5-12.

- Stages in the Revolution: Political Theatre in Britain since 1968. London: Eyre Methuen, 1980.

Judd, Judith. "Journalists' Shock Drama Probe at the National." Observer 26 Oct. 1980.

Lahr, John. "The Cruelty of Theatre." Misc. Rev. New Society 23 Oct. 1980: 173-4.

Levin, Bernard. "Conquered by the Romans on the South Bank." Rev. Times 11 Mar. 1981.

Lewis, Peter. The National: A Dream Made Concrete. London: Methuen, 1990.

McMullen, Richie J. Male Rape: Breaking the Silence on the Last Taboo. London: Gay Men's, 1990.

Milligan, Spike. Letter. New Standard 21 Apr. 1981.

Murray, Oswyn. "Stories of Imperialism: Romans and Celts ..." Rev. of Romans. Times Literary Supplement 24 Oct. 1980: 1199.

Nightingale, Benedict. "Mailed Fist \& Iron Heart." Misc. Rev. New Statesman 24 Oct. 1980: 28.

Oakes, Philip. "Caesar on the South Bank." Rev. of The Romans. Sunday Times 12 Oct. 1980: 39.

O'Connor, John Edward. Revolution and the Society of the Spectacle: A Critical Analysis of Selected Plays by Howard Brenton. Diss. U of Washington, 1989.

Olivier, Laurence. Letter. Times 22 Oct. 1980: 13.

Osborne, John. Letter. Guardian 23 Oct. 1980. (Rpt. in Mitchell 43.)

Ottoway, James. Letter. Times 22 Oct. 1980: 13.

Pinter, Harold. Letter. Guardian 5 Nov. 1980.

Ponnuswami, Meenakshi. "Celts and Celticists in Howard Brenton's

The Romans in Britain." Journal of Dramatic Theory and Criticism 12.2 (1998): 69-88.

Rayside, David M. "Homophobia, Class and Party in England."

Canadian Journal of Political Science 25.1 (1992): 121-49. Rissik, Andrew. "The Henry Trilogy." Rev. of The Henrys, directed 
$86 /$ Defraeye

by Michael Bogdanov. Plays and Players 402 (Mar. 1987): 8-11.

Roberts, Philip. "The Trials of The Romans in Britain." Wilson 5970.

Rooney, Ellen. "Criticism and the Subject of Sexual Violence." Modern Language Notes 98.5 (1983): 1269-78.

Shulman, Milton. Letter. Guardian 12 Nov. 1980.

Sutherland, John. Offensive Literature: Decensorship in Britain, 1960-1982. London: Junction, 1982.

Veyne, Paul. "Homosexuality in Ancient Rome." Western Sexuality: Practice and Precept in Past and Present Times. Ed. Philippe Ariès and André Béjin. Oxford: Blackwell, 1985. 26-35.

Weiner, Bernard. "The Romans in Britain Controversy." The Drama Review 25.1 (1981): 57-68.

Wilson, Ann, ed. Howard Brenton: A Casebook. New York: Garland, 1982.

Young, B.A. "The Romans in Britain." Rev. Financial Times 18 Oct. 1980.(Rpt. in The Mirror up to Nature: A Review of the Theatre: 1964-1982. London: Kimber, 1982. 133-34. 